\title{
TRADE, TAX AND TAKEOVERS - CAN THE EUROPEAN COURT DE-REGULATE EUROPE DESPITE RESISTANCE FROM THE COUNCIL AND PARLIAMENT ${ }^{1}$
}

\author{
Derrick Wyatt*
}

Summary: Proposals by the Commission to remove barriers to cross-frontier business activity seem deadlocked by disagreement in the Council or Parliament (e.g. Tax Harmonisation and the Services Directive) or doomed to produce European packaging for business as usual (e.g., the Takeover Directive). It is the Luxembourg Court which maintains the process of de-regulation, and upholds challenges to national rules on banking, tax, and capital structures, which operate as barriers to market entry and reduce the competitiveness of the European market. For those who believe in free markets, these contributions to a competitive Europe are timely and positive.

This lecture advances two propositions. The first concerns the European Court's contribution to a competitive European market. It falls to the Court to interpret the scope of the fundamental freedoms of establishment, service provision and capital movement. The Court's approach in this respect has contributed positively to the high degree of competitiveness referred to in Article 2 of the EC Treaty. My second proposition is that the Community's political institutions, the Council and the Parliament, have inhibited recent Commission initiatives to de-regulate the internal market, and improve its overall competitiveness.

Perhaps the most significant case ever decided by the Court of Justice in the internal market field was the so-called Cassis case. ${ }^{2}$

Under German legislation fruit liqueurs such as "Cassis" could only be marketed if they contained a minimum alcohol content of 25 per cent., whereas the alcohol content of the French product in question was between 15 per cent and 20 per cent

The Court in this case, in 1979, laid down an important principle. It held that there was no valid reason why alcoholic beverages lawfully produced and marketed in one of the Member States, should not be introduced into and placed on the market in any other Member State. A product which was good for the market of one Member State, was presumptively good for the markets of all Member States, unless there was an objectively justifiable reasons to the contrary. National rules which failed to respect this principle must be set aside by national courts.

\footnotetext{
${ }^{1}$ This is the text of a lecture delivered to Oxford alumni in London on $23^{\text {rd }}$ May at the offices of Allen and Overy.

- Professor Derrick Wyatt QC, St Edmund Hall, Oxford

${ }^{2}$ Case 120/78 Rewe-Zentral AG v Bundesmonopolverwaltung für Branntwein [1979] ECR 649.
} 
The same principle was to be adopted for services, in Säger v Dennemeyer \& Co. Ltd. ${ }^{3}$

The national proceedings arose from a legal action by a patent agent in Munich against a company incorporated in England and Wales. The plaintiff was a specialist in patent renewal services who claimed that the provision of such services by the defendant to customers in Germany was contrary to German rules reserving such activities exclusively to persons possessing the relevant professional qualification.

The Court held that the Treaty prohibited any national rule likely to impede the activities of a provider of services established in another Member State where he lawfully provides similar services. A service product which is good for the market of one Member State, is presumptively good for the market of all Member States, unless there are objectively justifiable reasons to the contrary.

In the latter case an English company lawfully providing services in the UK was held to be entitled to provide its services to customers in Germany. In a more recent case the Court allowed a service provider to challenge rules in its country of establishment, on the ground that those rules prevented the service provider from providing the prohibited service to customers in other Member States. ${ }^{4}$ Swedish rules prohibited the advertising in publications of alcoholic beverages. The Court of Justice held that such a prohibition amounted to a restriction on the provision of services which would have to be justified. This was because (a) the prohibition restricted the right of publishers to offer advertising space to potential advertisers in other Member States and (b) the prohibition had a particular effect on the cross border supply of advertising space, given the international nature of the advertising market in alcoholic products. This judgment shrinks the distinction between inter-State transactions and purely internal intra-State transactions almost to vanishing point. ${ }^{5}$

Good and services have something in common. They can originate in one Member State, yet be marketed in another. There is a kind of logic in allowing the rules of the state of origin to determine legal requirements relating to the essential characteristics of goods or services. The purchaser in one Member State of a good or service originating in another, is in a sense "shopping abroad". The German consumer of French cassis could be said to be doing so. As could the German consumer of British patent renewal services.

Businesses aiming to set up permanent establishments in other Member States seem at first sight to raise rather different issues. The aim of the out of state business is to become an in-state business. The guarantee essential to achieving that aim is the prohibition of discrimination on grounds of nationality. Until relatively recently it appeared that a national rule could only amount to a restriction on the right of establishment if it discriminated, directly or indirectly against out of state businesses.

\footnotetext{
${ }^{3}$ Case C-76/90 Manfred Säger v Dennemeyer \& Co. Ltd [1991] ECR I - 4221.

${ }^{4}$ C-405/98 Gourmet International Products [2001] ECR I - 1755

${ }^{5}$ As does Case C-60/00 Mary Carpenter [2002] ECR I - 6279
} 
In Commission v. Belgium ${ }^{6}$ the Commission alleged that non-discriminatory Belgian rules governing the activities of clinical biology laboratories were incompatible with Article 43 (ex 52). The Commission argued that the rules in question were excessively restrictive, and that the latter Article prohibited not only discriminatory measures, but also "measures which apply to both nationals and foreigners without discrimination where they constitute an unjustified constraint for the latter." 7 The Court rejected this approach to the right of establishment. It emphasised that the text of Article 43 (ex 52) guaranteed equality of treatment for nationals and non-nationals, and stated:

".. provided that such equality of treatment is respected, each Member State is, in the absence of Community rules in this area, free to lay down rules for its own territory governing the activities of laboratories providing clinical biology services." 8

This position was soon to change. In the Gebhard ${ }^{9}$ case the Court made it clear that any national measure which hindered or made less attractive the exercise of the right of establishment, must be justified, whether discriminatory or not. While the Court adopted this approach in a case which involved the right of establishment, the Court used a formulation which referred to the exercise of all fundamental freedoms.

“...national measures liable to hinder or make less attractive the exercise of fundamental freedoms guaranteed by the Treaty must fulfill four conditions: they must be applied in a non-discriminatory manner; they must be justified by imperative requirements in the general interest; they must be suitable for securing the attainment of the objective which they pursue; and they must not go beyond what is necessary in order to attain it (see Case C-19/92 Kraus..., para. 32). ${ }^{10}$

This approach is clearly more demanding of national rules than a mere nondiscrimination requirement. One effect of the Gebhard formulation may be to create a presumption that a commercial operator carrying on business under certain conditions in its home state is entitled to extend its activities to another Member State under the same conditions. This is analogous to the weight which the Cassis and Säger principles give to the law of the Member State of origin of goods and service products.

This proposition is demonstrated by the judgment in the now well known Centros case. ${ }^{11}$ In this case the Court treated the right of establishment as including the right of a company incorporated in one Member State to set up a branch in another, even if the company carried on no business at all in the Member State of incorporation, and did not comply with the minimum capital requirements of the Member State where the branch was established.

\footnotetext{
${ }^{6}$ Case 221/85 Commission v. Belgium [1987] ECR 719.

${ }^{7}$ Ibid., para. 5 .

${ }^{8}$ Ibid., para. 9. The Court confirmed this view of the scope of freedom of establishment in Case 198/86 Erwin Conradi and others v. Direction de la Concurrence et des Prix des Hauts de Seine [1987] ECR 4469.

${ }^{9}$ Case C-55/94 Reinhard Gebhard v. Consiglio dell'Ordine degli Avvocati e Procuratori di Milano [1995] ECR I - 4165.

${ }^{10}$ Ibid., para. 37.

${ }^{11}$ Case C-212/97 Centros Ltd v. Erhvervs- og Selskabsstyrelsen [1999] ECR I - 1459.
} 
Danish nationals resident in Denmark and carrying on business in Denmark set up a limited liability company in England whose only business activities would be carried out by a branch in Denmark. The share capital of the English company was $£ 100$, and the sole reason the Danish nationals set up a company in the United Kingdom rather than Denmark, was to secure the advantages of limited liability without having to meet the cost of the $£ 20,000$ minimum capital requirement then prevailing in Denmark. When the Danish nationals sought to register the Danish branch of the company, the Danish authorities refused to do so, since that branch would be the principal establishment of the English company, which would do no business in the United Kingdom, and since the sole purpose of setting up the English company was the avoidance of Danish minimum capital requirements. The Danish authorities regarded the situation as in reality being internal to Denmark, but made it clear that they would have registered the branch if the company had been also carrying on business in the United Kingdom.

The Court in this case upheld two related aspects of the right of establishment. The first aspect was the right of a person who wished to set up a company to choose the Member State whose company law was the least restrictive. The second aspect was for that company to set up a branch in any other Member State. The Court rejected arguments that these features represented an abuse of the right of establishment - these features were "inherent in the exercise, in a single market, of the freedom of establishment guaranteed by the Treaty." 12

It is not difficult to draw an analogy between Centros on the one hand, and Cassis and Säger on the other. The analogy is to the effect that just as a good or service product produced in one Member State may in principle be marketed in any other Member State, so may a company incorporated in one Member State claim to be recognised as such in any other Member State. The analogy with Cassis was indeed part of the argument of the United Kingdom at the hearing in the Centros case.

The presumption which may be created by the right of establishment to the effect that a commercial operator carrying on business under certain conditions in its home state is entitled to extend its activities to another Member State under the same conditions appears from other case law. In Pfeiffer Gro8handel ${ }^{13}$ an Austrian subsidiary of a German parent operating 139 discount stores in Austria wanted to use the trade name "Plus". This was the trade name used by the German parent in its German stores, and German parent wished to extend this "own brand" name to its stores in Austria. Another company claimed that the trade name infringed its rights to use a similar name, and sought a restraining order. The Court referred to the Gebhard test and stated:

"A restraining order of the type sought by the plaintiff in the main proceedings operates to the detriment of undertakings whose seat is in another Member State where they lawfully use a trade name which they would like to use beyond the boundaries of that State. Such an order is liable to constitute an impediment to the realization by those undertakings of a uniform advertising concept

\footnotetext{
12 Ibid., para. 27.

${ }^{13}$ Case C-255/97 Pfeiffer Gro8handel Gmbh v. L $\overline{w a}$ Warenahndel Gmbh [1999] ECR I - 2835.
} 
at Community level since it may force them to adjust the presentation of the businesses they operate according to the place of establishment." ${ }^{14}$

The Court of Justice recognised that such a restriction might be justified, but what is significant is that the Court recognises as part of the right of establishment the right to realise a "uniform advertising concept at Community level". What this right amounts to in a case such as Pfeiffer is the benefit of a presumption that the advertising concept used by the parent in the home State may be extended to other Member States, unless there is a good reason to the contrary.

One of the effects of the Gebhard formulation may be to create a presumption that a commercial operator carrying on business under certain conditions in its home state is entitled to extend its activities under the same conditions to another Member State. But the Gebhard formulation is not limited to such an affect and appears to allow a commercial operator to challenge any national rule which hinders or makes less attractive the exercise of the right of establishment. The extent to which this allows out of state commercial operators to challenge allegedly unnecessary regulation is illustrated by the recent Caixa Bank case. ${ }^{15}$ This case concerned French rules prohibiting interest on "sight" current accounts. A French subsidiary of a Spanish bank wished to pay interest on its current accounts. It alleged that the French rules constituted a restriction on the freedom of establishment in so far as they applied to a subsidiary formed in France by a legal person registered in another Member State. The Court agreed:

12. A prohibition on the remuneration of sight accounts such as that laid down by the French legislation constitutes, for companies from Member States other than the French Republic, a serious obstacle to the pursuit of their activities via a subsidiary in the latter Member State, affecting their access to the market. That prohibition is therefore to be regarded as a restriction within the meaning of Article $43 \mathrm{EC}$.

13. That prohibition hinders credit institutions which are subsidiaries of foreign companies in raising capital from the public, by depriving them of the possibility of competing more effectively, by paying remuneration on sight accounts, with the credit institutions traditionally established in the Member State of establishment, which have an extensive network of branches and therefore greater opportunities than those subsidiaries for raising capital from the public.

14. Where credit institutions which are subsidiaries of foreign companies seek to enter the market of a Member State, competing by means of the rate of remuneration paid on sight accounts constitutes one of the most effective methods to that end. Access to the market by those establishments is thus made more difficult by such a prohibition."

The rule in issue in this case hinders the right of establishment because it reinforces barriers to market entry which are intrinsic to the banking sector - the existence of an extensive network of branches. What if the subsidiary of the out of state bank has a network of branches itself? It does not seem to be a precondition to challenging the national rule that the out of state bank actually be placed at a disadvantage by the

\footnotetext{
${ }^{14}$ Ibid., para. 20.

${ }^{15}$ Case C-442/02 CaixaBank France, Judgment of 5 October 2004.
} 
national rule in question. In principle, the national rule reinforces barriers to market entry, and that seems to be enough for an out of state operator to challenge the rule.

A fundamental freedom closely linked to the right of establishment is the right to free movement of capital. The links are particularly close when it comes to acquiring shares in companies with a view to the exercise of managerial control. The Court has given judgment in a number of cases involving "special shares" held by public authorities in companies previously in public ownership. The shares were "special" in that they bestowed voting rights did not reflect any capital invested by the State, and in that the existence of the special shares was the direct or indirect consequence of national legislative measures. These special shares bestowed on the public authorities the right to veto certain acquisitions of shares in the company, and to veto certain decisions of the company. Of particular interest are those cases in which the existence or exercise of the special share rights did not have any discriminatory effects whatsoever. The Court held in one of the cases, Commission v. France ${ }^{16}$ that

"Even though the rules in issue may not give rise to unequal treatment, they are liable to impede the acquisition of shares in the undertakings concerned and to dissuade investors in other Member States from investing in the capital of those undertakings."

The Court's reasoning is to the effect that an investor seeking to acquire a controlling stake in a company is likely to be dissuaded from doing so if a Member State retains special rights to interfere in the management of the company by its directors. This comes close to saying that regulation of corporate activities per se amounts to a restriction on capital movement.

The Court's case law on goods, services, establishment and capital movement has two effects. It removes obstacles to cross frontier economic activity. And it does so in a way which contributes to a high degree of competitiveness, since all that is necessary to show a restriction on cross frontier economic activity is a hindrance to the exercise of the economic activity itself. This case also tends to shrink the distinction between purely internal situations and cross frontier situations. Thus for example in the special shares cases, provisions in the articles of association which gave state authorities special rights were held to amount restrictions on capital movement, since they were capable of dissuading potential investors from other Member States from investing in the companies in question. Yet they had no special propensity to hinder cross frontier activity. One effect of expanding the reach of the internal market is to increase the pro competitive effects of the Court's case law. A side effect of this expansion is an expansion in competence of the Community institutions to regulate the internal market under, inter alia, Article 95 EC.

A feature of the right of establishment and of capital movement which has attracted increasing attention has been its impact on the application of national tax rules. Tax lawyers came late in the day to the implications of the internal market for national tax rules. Of all the cases involving national tax provisions heard by the Court between

${ }^{16}$ Case C-483/99 Commission v. France [2002] ECR - 4781, para. 41. 
1990 and 2000, two thirds of the cases dated from the last three years of that period. ${ }^{17}$ Aspects of national tax law hitherto regarded as the reasonable corollaries of the territorial scope of the tax systems, have increasingly been regarded by the European Court as hindering the exercise of fundamental freedoms or discriminating on grounds of nationality. UK rules depriving a resident company of consortium relief because of the inclusion of a certain proportion of non resident companies in the consortium have been held to hinder the right of establishment. ${ }^{18}$ French rules automatically subjecting unrealised capital gains to tax, when a taxpayer transfers his tax residence to another Member State, have also been held to amount to a restriction on the right of establishment. ${ }^{19}$ And "thin capitalisation" rules, applying to loans by out of state parent companies to their subsidiaries, but not to loans by resident parent companies, have been held to discriminate on grounds of nationality. ${ }^{20}$ The effect of Court's case law in this area as in others is market liberalising, or potentially so. I would maintain this to be the case even though in certain cases the response of Member States has been to respond to the Court's case law by extending to internal situations tax regimes hitherto reserved for cross frontier situations. And even though one of the aims of the Court of Justice might well be to encourage measures of harmonisation. $^{21}$

My thesis tonight is that the case law of the European Court has been and continues to be a liberalising force which should be welcomed and supported by those who consider free markets to make a substantial contribution to the public good.

But there is a second element in my thesis. It is that the Council and Parliament are not playing the positive role which they might. The Commission has never been more liberal, in the economic sense. This is not a comment simply or mainly on the Barroso Commission. The evolution of the pro market attitudes of the Commission certainly predates the present Commission, and has affected the Commission's approach to the content of internal market legislation which it has proposed for adoption to the Council and European Parliament in order to facilitate exercise of the right of establishment and the freedom to provide services.

In this connection it should be recalled that the legal basis of company law harmonisation in the EC Treaty is the chapter on establishment. The decision of the European Commission to appoint a High Level Group of Company Law Experts to advise on proposals for company law harmonisation has ensured that subsequent

17 Wathelet, The Influence of Free Movement of Persons, Services and Capital on National Direct Taxation:Trends in the Case Law of the Court of Justice, 20 YEL (2001) 1, p. 32.

${ }^{18}$ Case C-264/96 Imperial Chemical Industries plc (ICI) v Kenneth Hall Colmer (Her Majesty's Inspector of Taxes) [1998] ECR I - 4695.

${ }^{19}$ Case C-9/02 Hughes de Lasteyrie du Saillant v. Ministère de l'Économie, des Finances et de l'Industrie Judgment of 11 March 2004.

${ }^{20}$ Case C-324/00 Lankhorst-Hohorst GmbH v. Finanzamt Steinfurt [2002] ECR I - 11779.

${ }^{21}$ Judge Melchior Wathelet (reporting judge in numerous tax cases) wrote: "It may be that, if there is a continuing increase in the number of cases brought, either before the Court of Justice or before the national courts, that will force the Member States to accelerate moves towards a harmonisation of national laws" (2001 YEL, p. 33). 
Commission proposals have taken account of the views of business and have aimed to adjust company law to facilitate the right of cross frontier establishment, not simply to create interesting hybrid company law. The First Report of the High Level Group of Experts Group was on the proposed Take-over Directive. The Second Report was on "A Modern Regulatory Framework for Company Law in Europe". This latter report was presented in November 2002. Its values are unequivocally the new European values of competitiveness, and empiricism, combined with a methodology which emphasises transparency and consultation.

Council and Parliament failed to adopt the Take-over Directive in the form advocated by the Commission. In the form proposed by the Commission the directive would have had distinctive pro market and pro competitive features. In the first place the directive prohibited action by the board of a target company to frustrate a bid without the prior authorisation of the general meeting. In the second place multiple voting rights and restrictive voting arrangements would not have had effect at any general meeting authorising defensive measures. Such a Directive would have improved competitiveness in the internal market by preventing self-serving defensive measures by company boards. But pressure from certain Member States led to these provisions of the Take-over Directive being considerably weakened. ${ }^{22}$ It is possible for example for Member States to opt out of the rules on defensive measures/voting rights in Articles 9 and 11 of the Directive. Yet companies in those Member States may nevertheless opt into the regime of Articles 9/11. And Member States may authorise companies not to apply Articles $9 / 11$ if they are the subject of a takeover by a company which does not apply that regime. So in countries which apply Articles $9 / 11$, target companies cannot frustrate bids by home companies, but may be entitled to frustrate bids by companies subject to the law of a Member State which has opted out of Articles 9/11, unless the company in question has opted into the latter regime! The Commission's proposal was for a European wide take-over regime that would have made for a more competitive Europe. It was modified into a regime which allows Member States to adopt protectionist opt outs which are hard to reconcile with the aims and scope of the chapter on establishment.

This example - of a Commission proposal for improvement of the internal market being undermined by Member States and/or the European Parliament - is not isolated. The proposal for a directive on services in the internal market ${ }^{23}$ is a good model of how internal market legislation should be conceived, developed and formulated. The need for the legislation is based on empirical rather than speculative or theoretical grounds. ${ }^{24}$

\footnotetext{
${ }^{22}$ Directive 2004/25/EC of the European Parliament and of the Council of 21 april 2004 on takeover bids, OJ L108/38.

${ }^{23} \operatorname{COM}(2004) 2$ final/3; Council document 5161/05 of 10 January 2005.

${ }^{24}$ See the Commission report on "The State of the Internal Market for Services" COM (2002) 441 final, 30.7.2002. In its "subsidiarity" evaluation, the Commission states that "The obstacles in question have been clearly identified on the basis of complaints, petitions and questions from the European Parliament, consultation of interested parties, and studies or analyses."
} 
The scheme of the directive as regards establishment provides for administrative simplification. It lays down a presumption against the need for authorisation schemes unless objectively justified. ${ }^{25}$

The scheme of the directive for provision of services places reliance on the origin principle. This is the principle that services be in principle be regulated by their "home State". ${ }^{26}$

Harmonisation of standards is kept to a minimum and targeted.$^{27}$ Codes of conduct at Community level are advocated in circumstances where in the past harmonisation might have been preferred. ${ }^{28}$ Voluntary policies on the quality of services and charter marks are similarly advocated. ${ }^{29}$

The provisions of the directive as regards both establishment and services are significantly influenced by the case law of the Court of Justice, and in a number of respects the directive is declaratory of the effects of directly effective treaty provisions on establishment and services. This is light touch regulation aimed at deregulation. It is a logical step towards implementation of the so-called Lisbon agenda, and was indeed described by the Commission as a relaunch of this agenda. Yet is has proved in some quarters highly controversial. In particular aspects of the directive have been strongly criticised by the governments of several large Member States. What is particularly worthy of remark in this respect is that criticisms of this directive appear to call in question basic treaty principles, as those principles have been interpreted by the European Court of Justice.

My final example of the Court and Commission being rather more enthusiastic than national governments about removing barriers in the internal market, is in the tax field. With few exceptions, the Court's case law on fundamental freedoms versus national tax rules rightly identifies unjustifiable restrictions on cross frontier economic activity. Objections to this case law are largely objections by national finance ministries concerned at erosion of the national tax base. There is room to argue that the case law of the Court has in one or two cases given insufficient weight to the need to allow derogations from fundamental freedoms in the interest of a mandatory requirement which has come to be described as the "cohesion of the tax system" $^{\prime 30}$ (or in analogous arguments for derogation). I would say for example that if the Court of Justice were to accept the contention of the taxpayer in the national proceedings in Case C-446/03 Marks \& Spencer v. David Halsey (HM Inspector of Taxes), this would be a step too far. This might not, admittedly, be the case if the Opinion of Advocate General Maduro were accepted by the Court. But the

${ }^{25}$ Articles 9 and 10.

${ }^{26}$ Articles $16-19$.

${ }^{27}$ Article 40.

${ }^{28}$ Article 39.

${ }^{29}$ Article 31.

${ }^{30}$ The principle was applied in Case C-204/90 Bachmann, [1992] ECR I - 249, but has been construed very narrowly in subsequent cases, as have analogous arguments, see e.g., Case C-264/96 Imperial Chemical Industries plc (ICI) v Kenneth Hall Colmer (Her Majesty's Inspector of Taxes) [1998] ECR I - 4695, paras. 28 and 29. 
fundamental problem with the argument advanced by the taxpayer in Marks and Spencer is with the proposition that one Member State should be obliged to give relief for losses incurred in another Member State in respect of activities falling wholly outside the tax competence of the first Member State. ${ }^{31}$

Whether or not the Court of Justice might in certain cases have failed to have sufficient regard for the "cohesion" of the national tax systems, the concern of national finance ministries that the Court's case law is eroding and will continue to erode the national tax base is a legitimate concern. But it is a concern which can be addressed. It can be addressed by unilateral modification of tax rules, in some cases by double tax conventions, and it can more ambitiously be addressed by the Community institutions adopting harmonisation measures via Article 94 of the EC Treaty. The Commission's position is to pursue the long term aims of (a) a common tax base and (b) home state taxation for small and medium sized enterprises.

While in theory a common tax base is about the best cause the European law maker could champion in the tax field, consensus might only be possible via enhanced cooperation on the part of certain but not all Member States.

Qualified majority voting in the tax field is legally out of the question, now and under the draft Constitution, and would be disastrous in policy terms because some Member States would seek to impose high minimum rates of corporation tax, and thus undermine the overall competitiveness of the EU. But Member States which want a competitive low tax Europe should not regard any tax harmonisation as bad harmonisation. A common tax base, negotiated by unanimity to safeguard national fiscal sovereignty, could produce policy gains for Member States, and a reduction in arbitrary tax penalties for companies extending their businesses across national frontiers.

The Common Consolidated Corporate Tax Base Working Group, which had its first meeting in November 2004, continues to meet. But at the outset two Member States indicated that a distinction was to be drawn between technical participation and the political aspects of the common tax base project. The two Member States in question remained politically opposed to a common tax base. The possibility that progress at the technical level might lead to modification of political positions cannot be ruled out. And adoption in the future of a common tax base by some Member States via the procedure of enhanced cooperation seems a distinct possibility.

It might be said that lawyers should confine their criticisms of lawmakers and judges to the technical aspects of the work of both. But in the field of European law, as in many national fields of law, a hard and fast line between legal reasoning and principle on the one hand, and policy and politics on the other, is not easy to draw. It is in that spirit that I venture the modest conclusion, that the contribution of the European Court of Justice to a Europe of personal freedom of movement, and indeed to a more

${ }^{31}$ Dr I.J. Ghosh, Tax Notes International ,4th April 2005. 
For citation please use CYELP, volume 1. More information available at www.cyelp.com

competitive Europe, has been distinctive, and enduring. It is to be hoped that at least the principal elements of that contribution prove irreversible. 